\title{
UNsatisfied? The Rocky Path to NATO Membership - Bosnia and Herzegovina: A New Approach in Understanding the Challenges
}

Hamza Preljević

\section{Abstract}

NATO's enlargement in the Western Balkans (WB) has been the focus of a number of debates for almost two decades. Opinions and positions regarding this question range from serious doubts, criticisms and opportunistic press releases to enthusiastic support for membership. This paper assesses Bosnian reforms and policy changes, as well as the country's efforts to join NATO. Bosnia and Herzegovina (BiH) has made significant steps in moving towards NATO's military and political standards, but not sufficiently. Although BiH is viewed by some observers as a country approaching the point of joining the Membership Action Plan (MAP), this prospect remains uncertain. The findings of this research suggest that BiH is different from other WB countries and that it is not suitable for understanding the NATO integration challenges in the WB. In order to understand Bosnian 'specifics', it is necessary not only to view the challenges through the prism of technical and other domestic issues in BiH. A wider approach must be adopted. Through understanding the Bosnian specifics, the dilemmas related to the NATO membership of BiH become more obvious and clear. Bosnian specifics illustrate why BiH is not able to take significant steps towards long-term stabilization and NATO membership.

KEY WORDS:

Bosnia and Herzegovina, NATO, challenges, specifics, regional influence 


\section{Introduction}

Since the end of the Bosnian war, Bosnia and Herzegovina (BiH) has accomplished several essential changes for successful transition into a more democratic society. The fundamental issues of this process of democratization are related to EU and NATO integration. In the Balkan context, "the promise of closer ties to the European Union and, to a lesser extent, to NATO have been key drivers for reform in the Western Balkans" (Benyon 2017: 5) following the dissolution of Yugoslavia.

$\mathrm{BiH}$ is a country aspiring to join NATO (NATO 2017c: i). It bases such an ambition on the progress it has achieved so far, as well as on its determination to implement essential reforms and to contribute to NATOled missions. In addition, $\mathrm{BiH}$ is located in a geographically important region - the military can easily be deployed to the Middle East, Northern Africa, the Black Sea region, Eastern Europe and Western Europe from this region (Milinkovich 2016: ii) - and has proved itself a worthy NATO partner.

However, BiH is faced with a number of concerns and challenges regarding NATO membership. Its integration process is marked with continued difficulties, though a significant number of positive successes have been achieved. NATO membership by $\mathrm{BiH}$ could be understood in terms of 'for better or for worse', depending on which ethnic group (Bosniak, Serb or Croat) one belongs to. The country has serious difficulties overcoming internal disputes in order to reach clear agreement on the key issues regarding vital national interests.

This paper analyses the issues that hinder the Bosnian NATO integration process. By analysing the Bosnian specifics, it is possible to understand that even NATO membership by BiH cannot be viewed in terms of its domestic issues, as it encompasses regional actors and issues. These specifics prevent $\mathrm{BiH}$ from taking faster steps towards long-term stabilization and NATO membership. The paper aims to explain the importance of domestic politics for the WB state's foreign policies. Also, the paper includes an analysis of the influence of neighbouring countries on Bosnian NATO integration. 


\section{Theoretical framework and discussion}

This paper first refers to some theoretical propositions as to reasons for alignment and the necessity for states to join an alliance. Most of the theories which define alliances and their nature are based on realist propositions. These assumptions explain the basic reason for alignment as the clear intention of two or more countries to aggregate their capabilities and powers because of fear of another country. Alliances are often regarded as the reaction to a threatening power. Alliances are sometimes created not only as a reaction to a power threatening their security, but as a reaction to the perceived threat. "States ally to balance against threats rather than against power alone. Although the distribution of power is an extremely important factor, the level of threat is also affected by geographic proximity, offensive capabilities, and perceived intentions" (Walt 1987: 5). This approach seems to be more applicable to understand the reasons why BiH should become a NATO member state. But joining an alliance does not have to deal only with power balancing or perceived threat. George Liska (1962: 30) in Nations in alliance: the limits of interdependence, identified three main reasons for alignment: "internal and international security, stability and status of states and regimes". Tatsuya Nishida suggests that "in general, the existence of a threat or hostile power is a necessary condition for developing a security alliance" (in Warren 2010: 11).

After the post-Cold War period, the number of countries that wanted to become NATO members increased. In some of the cases, the "theories of balance of power or balance of threat cannot adequately explain reasons for such behaviour" (Grizold and Vegic 2001: 127). The reasons to become a NATO member state became more complex, while NATO changed its raison d'être. On the other hand, the threats that remained part of the countries' history were for some states serious enough to encourage them to join NATO.

In order to understand the Bosnian NATO integration process, two other factors need to be included in the analysis: (i) the history of conflicts in $\mathrm{BiH}$ and its people; and (ii) substantial violation of some of the provisions of the Dayton Peace Agreement (DPA) - specifically, Annex 1-B: regional 
stabilization. Firstly, through analysing some of the key events in the history of $\mathrm{BiH}$, it can be concluded that the country has passed through many ethno-religious conflicts at both the inter-state and intra-state levels. Bosniaks, Croats and Serbs in BiH have fought against each other and all of the conflicts led to massive human and capital losses. In addition, Croatia and Serbia both laid claim to the territory of $\mathrm{BiH}$. The territorial pretension is demonstrated by the four strategic documents written by prestigious Serbian leaders and institutions: (i) Načertanije (1844) by llija Garašanin; (ii) Serbs All and Everywhere (1849) by Vuk Karadžić; (iii) Homogeneous Serbia (1941) by Stevan Moljević; and (iv) Memorandum (1986) by the Serbian Academy of Arts and Sciences (SANU) (see more: Croatian Information Centre 1993). All of these documents propose the spread of Serbian influence, mainly by propaganda and through a network of pro-Serbian rebels, the major goal being to create a favourable situation for Serbian national interests in $\mathrm{BiH}$. There is a lack of clear distancing from these tendencies among the political elites in Serbia. In addition, condemnation of the above-mentioned historical documents would play a significant role in establishing sustainable and peaceful relations with the neighbouring countries.

In addition, the Karađorđevo meeting of 25 March 1991 was a meeting on the issue to redistribute BiH between Croatia and Serbia. The meeting was attended by Croatian President Franjo Tuđman and Serbian President Slobodan Milošević, and their delegations. Judge Mark Brian Harmon, on 16 March 1998, announced witness Stjepan Mesić' before the Hague Tribunal in the case of General Tihomir Blaškić as follows:

"He [Stjepan Mesić] will testify about President Tuđman's dual policy towards Bosnia, one which was a public policy of recognition of the independence of Bosnia, and a clandestine policy to divide Bosnia between Croatia and Serbia. He will testify in that regard about a meeting that took place in 1991 between Slobodan Milošević and President Tuđman at Karađorđevo, after which President Tuđman's clandestine policy to divide Bosnia was implemented" (Case No IT-95-14-A1998a).

Prosecutor Gregory W. Kehoe accepted the assumption of the 
Karađorđevo meeting as a secret one (Case No IT-95-14-A1998b). Serbia aimed to secure the lands in eastern and western Bosnia. Croatia wanted to secure lands in $\mathrm{BiH}$ in which Croats were the majority. This plan was magnified when Milošević supported Serbs in Croatia to commit horrible war crimes against Croats, including ethnic cleansing. On the other hand, other interpretations of this meeting [Karađorđevo] say that it is not convincing to make a secret agreement during a public meeting (Tuđman 2015).

Secondly, although the WB region remains unstable and there have been many instances of DPA violation, the possibility of a new war in $\mathrm{BiH}$ was substantially reduced with the implementation of the DPA. However, since it was signed, the world has witnessed continuous infringements of the DPA in many domains: in this study, only the military aspects are presented. Taking into account a history of ethno-religious conflicts and disputes, the international negotiators and mediators blueprinted longterm regional peace through Annex 1 (the military aspect) of the DPA. Signatories of the DPA agreed to authorize the Organization for Security and Co-operation in Europe (OSCE) to organize and conduct negotiations in order to establish regional - military capability (equipment) — balance in and around the former Yugoslavia "based on the approximate ratio of populations of the Parties" (United Nations 1995). This has been partially changed, but not annulled.

On 4 December 2014, BiH, Montenegro, Croatia and Serbia signed the Amendment to the Agreement on Sub-Regional Arms Control (Annex 1B, Article IV of DPA) at the 21 st OSCE Ministerial Council in Basel. The aim of this amendment was to introduce new measures for regional stabilization and arms control, wherein the Sub-Regional Arms Control Agreement was assigned to the four parties of the agreement: BiH, Serbia, Croatia and Montenegro. The transfer of this ownership was strongly supported by the OSCE, the EU and the Contact Group countries. " "The transfer of ownership is not a withdrawal of the International Community or an attempt to leave the countries alone in the process to come. Co-operation in all matters of arms control will remain with the OSCE, shifting from hands on assistance to a more supportive role," said Major General Michele Torres ${ }^{3}$ (OSCE

2 The United States, United Kingdom, France, Germany, Italy and Russia.

3 Personal Representative of the OSCE Chairperson-in-Office for Article IV, Annex 1-B. 
2014a: xi). Additionally, Didier Burkhalter, the OSCE Chairperson-in-Office and Foreign Minister of Switzerland, argued that "the Dayton Article IV Agreement has been-and remains-highly relevant for stability in the region and for the entire OSCE area. It serves as a model for other OSCE regions in order to enhance security and stability" (OSCE 2014b: vii). Article IV of the DPA provides legal methods and instructive inspections of the armaments in the Balkans. ${ }^{4}$ However, there is a significant gap between policy and practice of arms control.

Annex 1 of the DPA (even after the amendment) has been violated and not many studies have directly addressed this issue. The rivalry fuelling the ongoing arms race in the Balkans is a part of current politics, but it dates back to the collapse of Yugoslavia in the early 1990s. "Croatia would like to buy US artillery systems, while Serbia has put Russian missile defence systems on its wish list" (Deutsche Welle 2016: i). Also, Vučić agreed with Russian Defence Minister Sergey Shoygu that Russia would give to Serbia "six MiG-29 jets, 30 T-72 tanks and 30 BRDM 2 reconnaissance vehicles" (Pantovic 2016: iv). Additionally, Serbia received sophisticated military equipment from Belarus. Interestingly, Serbia also received "16 rubber boats with outboard engines, five snowmobiles and 10 portable devices for detecting explosives and narcotics" (Sputnik 2017: i) from China as a military donation. All of these donations are powerful weapons that significantly change the military balance and destabilize the WB region. In the sense of military alliances and foreign support, $\mathrm{BiH}$ is lagging behind its neighbours. Moreover, the best indicator that Annex 1 - 'regional stability' - is reshaped in the Balkans is the military strength rankings. For instance, Global Firepower ranked the armed forces of BiH 121st (Global Firepower 2017a), Serbia 83rd (Global Firepower 2017c) and Croatia 68th (Global Firepower 2017b) out of 133 countries.5 This clearly shows that Annex 1 did not provide regional stability and/or balance among the signatories of DPA, because BiH lags many places behind Serbia and Croatia. The differences are not so small as to be considered insignificant, but rather they are worrisome, since they have been clearly defined by the DPA.

Additionally, Serbia is the only state in the WB region that has no clear

4 It established control of conventional armaments in five separate categories: attack helicopters, armored combat vehicles, combat aircraft, battle tanks and artillery pieces. 
desire to join NATO and with a significant pro-Russian attitude. All the other countries have either been member states for a long time or are in the process of becoming members. The Croatian case is much different because it is a NATO member state, an organization with a friendly attitude towards $\mathrm{BiH}$. In other words, in case of Croatia, the regional stability has been reshaped with NATO membership because, as a NATO member, Croatia was requested to follow NATO standards in order to participate alongside other forces in NATO-led missions and later in EU-led missions. Being asked about the arms rivalry between Serbia and Croatia, Boris Jernić, the deputy defence minister of BiH, stated: "When Croatia purchased new weapons, no one from Serbia commented on it; now, when Serbia is doing so [buying new weapons], they comment [referring to Croatian media]", adding, and "when it comes to the modernization, the Armed Forces of Bosnia and Herzegovina (AFBiH) have a very limited budget, because significant amounts of resources are being spent on the maintenance of existing [military] capacities. We do not have demands, and in the upcoming period, I think that it [the modernization] will not come and with the current budget that we have, we surely cannot follow Serbia and Croatia" (BN 2015: vii, author's translation). Nevertheless, the budget is not the main challenge. Milorad Dodik, President of Republika Srpska (RS), stated that he would ask the National Assembly of RS (NARS) to withdraw the deceleration of RS's commitment to Euro-Atlantic integration and accept a new deceleration for military neutrality, and for NARS to make a decision on further steps for the demilitarization of $\mathrm{BiH}$ (for more, see BN 2017: vi-ix; Faktor 2017: iii-iv). Such a policy is presented in the willingness of RS to follow the military status of Serbia (Radio Slobodna Europa 2016: iii). In addition, the policy of demilitarization directly conflicts with the DPA and Annex 1, because if BiH were left without military forces, it would be difficult to measure the regional stability among the signatories of DPA.

However, although from the above it can be concluded that $\mathrm{BiH}$, in order to secure its borders, should become a NATO member state, the ethnic groups (Bosniaks, Croats and Serbs) have divergent attitudes towards NATO. The geopolitical rivalry between Serbia and Croatia and the NATO membership of BiH could be understood in terms of which ethnic group one belongs to. Therefore, the NATO membership of BiH cannot be viewed only as a reaction to threatening power, but rather as a reaction 
to perceived threat, too. With membership of NATO, the balance of power promised under Annex 1-B of DPA would return to the region, and especially to BiH. Additionally, James D. Fearon (1998: 1) suggests that "a significant amount of recent research in the international relations (IR) field advances the proposition that domestic politics is typically a crucial part of the explanation for states' foreign policies". Scholars of comparative politics argue that the foreign orientation of a country cannot be understood without understanding the domestic politics. When it comes to $\mathrm{BiH}$, one could ask whether the domestic politics area product of the foreign policy, or the foreign policy a product of the domestic politics. This paper defines four specifics of $\mathrm{BiH}$ - created by both internal and external factors - that shape the country's NATO integration process. Understanding the country's specifics will provide a better insight into the way the domestic politics influence the NATO integration process, as well as into the foreign policy choice of BiH that seems to depend mostly on the issues of domestic politics.

\section{Status and issues of the Bosnian NATO integration process}

$\mathrm{BiH}$ joined the Partnership for Peace programme (PfP) in 2006. The PfP is a programme of practical bilateral cooperation, a platform for individual Euro-Atlantic partner states interested in cooperating with NATO and making use of different NATO programmes (NATO 2017a: i). It is a mechanism that leads to an opportunity to develop official cooperation with NATO. The focal points of the cooperation are democratic, institutional and defence reforms. In order to proceed with the process of becoming a member state, the relations of a country with NATO must keep expanding into new fields. In September 2008, the political elites in $\mathrm{BiH}$ agreed to launch the Individual Partnership Action Plan (IPAP). IPAP introduced new forms of cooperation between BiH and NATO. This led to a shift from purely defence to political issues. It is designed to "bring together all the various cooperation mechanisms through which a partner country interacts with the Alliance, sharpening the focus of activities to better support their domestic reform efforts" (NATO 2017a: i), as well as 
to "develop affordable capabilities for their own security needs" (Pond 2004: x). Also, cooperation under the IPAP includes implementation of the reform processes necessary for creating preconditions for NATO membership. BiH moved through IPAP evaluation cycles from 2008 to 2010 (Ministry of Defence of $\mathrm{BiH} 2011$ 1). The first IPAP was agreed between NATO and BiH in September 2008 (NATO 2017a: vi) and an updated IPAP version was agreed in September 2014 (NATO 2017c: xxii).

BiH has also been participating in the PfP Planning and Review Process (PARP) since May 2007. The participation of partner countries in PARP is a precondition for joining the Membership Action Plan (MAP). This is a tool used to identify "capabilities that could be available to the Alliance for multinational training, exercises and operations" (NATO 2014b: xxiv). Based on the Euro-Atlantic Partnership Work Plan (EAPWP), all members of the NATO PfP are required to develop their Individual Partnership Programme (IPP): it covers a period of two years, but revision and updates are made annually (Defence Reform Commission 2003). The IPP is approved by the Political-Military Steering Committee on Partnership for Peace (PMSC) and is proposed by the PfP member countries. According to the Defence White Paper of $\mathrm{BiH}$ (2005), the country expressed the priorities for cooperation in its IPP "in the areas that will enhance the establishment of command, control, communication and information systems, planning and budgeting, resource management and training and equipping; these will facilitate internal and external interoperability, and thus enhance the operational capabilities of the Armed Forces of $\mathrm{BiH}(\mathrm{AFBiH})$, particularly with respect to peace support and humanitarian operations" (p. 17). Beyond participation in these mechanisms, BiH has signed and ratified the PfP Status of Forces Agreement (SOFA) with NATO. This multilateral agreement deals with the status of foreign forces while present on the territory of another state (NATO 2014a: i). Through the NATO PfP programmes, BiH enables the country's AFBiH to participate in NATO's military activities and trainings in the country (e.g. the military exercise Combined Endeavour 2009, Banja LuKa, BiH) and abroad, through a series of activities contained in the Individual Partnership Programme. Also, since 2009, members of AFBiH have deployed and contributed to the International Security Assistance Force (ISAF) mission in Afghanistan.

In June 2009, the Presidency of BiH decided to apply for MAP. Soon 
after, on 2 October 2009, the BiH delegation, led by the Chairman of the Presidency of $\mathrm{BiH}$, Željko Komšić, submitted an application to join MAP. NATO welcomed the progress and reforms in BiH and in April 2010 the Allance invited BiH to join MAP. During the Tallinn Summit, NATO Foreign Ministers authorized the North Atlantic Council (NAC) in Permanent Session to accept BiH's Annual National Programme once a key remaining issue of immovable defence property had been resolved.

Unlike the other mechanisms, mostly technical in their nature, MAP is purely political, and that is one of the main reasons for the Bosnian failure to join MAP. Many political failures resulting from political disagreement and lack of cooperation between political elites regarding the requirement that all immovable defence properties be registered as state property prevent $\mathrm{BiH}$ from joining MAP. In his speech delivered on 29 June 2011, NATO Secretary General Anders Fogh Rasmussen called on the political leaders of $\mathrm{BiH}$ "to demonstrate vision, leadership and the ability to compromise, and to continue on the path of political and economic reform. A solution to the property issue would demonstrate that BiH functions like one state. That it is capable to interact with NATO and to fulfil its commitments within the Membership Action Plan" (NATO 2011: xix-xx). Once BiH meets these conditions, ANP could be immediately activated as a mechanism and document under MAP.

Under strong pressure from the international community in $\mathrm{BiH}$, six main ruling party leaders ${ }^{6}$ finally agreed on 9 March 2012 on the "registration and use of military and state property, long-running disputes which had held up Bosnia's Membership Action Plan (MAP) with NATO" (International Crisis Group 2012: 10). At the NATO Chicago Summit in May 2012, Alliance leaders welcomed the political consensus in BiH (NATO 2012: xxviii), but the agreement was delayed soon after. Furthermore, in order to meet the conditions defined under NAC, the Presidency of BiH identified sixty-three prospective military locations and the Ministry of Defence of $\mathrm{BiH}$ prepared two strategic documents - The Agreement on the Implementation of Agreed Principles of Distribution of Property and The Decision to Use Immovable Defence Property — for the Council of Ministers to initiate the process. In addition, the Council of Ministers established a working group

6 The six included the Croatian Democratic Union (HDZ), the Croatian Democratic Union 1990 (HDZ 1990), the Alliance of Independent Social Democrats (SNSD), the Serb Democratic Party (SDS), the Party of Democratic Action (SDA) and the Social Democratic Party of Bosnia and Herzegovina (SDP BiH). 
whose main task was to design a proposal to overcome disputes related to the registration of defence and/or state property. The leader of the Party of Democratic Progress, Mladen Ivanić (current Serb member of the Presidency), pointed out that the unsolved issue of defence property is an instrument to freeze the process of Bosnian integration into NATO, adding that "it is easier for [politicians from the Republika Srpska] to talk about a dispute over property than a dispute over membership in NATO" (Bećirević, Ćurak and Turčalo 2014: 34). Although BiH has made progress in many technical aspects and mechanisms, the state is still stagnating regarding the NATO membership process because every Law on State Property has been ignored by the political elite in the Republika Srpska. Also, according to the Ministry of Defence of BiH (201 1: 21), "due to the failure to meet the condition attached with regard to immovable prospective defence property, the ANP document was put on ice and the implementation of the IPAP, as the previous mechanism of cooperation with NATO, was reactivated". This state of affairs regarding MAP will therefore remain unchanged until the authorities of $\mathrm{BiH}$ meet a consensus for the registration of the immovable defence property. Lastly, once joined, MAP will outline preparations for possible future membership, but activation of MAP does not prejudge any decision by the Alliance on future membership. Once MAP is activated, the Alliance will still expect $\mathrm{BiH}$ to continue with reforms.

\section{Specifics of the Bosnian NATO integration process}

With its entrance into the NATO integration process, BiH identified its membership of NATO as one of the priorities of its foreign policy. Various declarations of parliaments, decisions of the Presidency of BiH, General Direction and Priorities for Implementation of Foreign Policy of Bosnia and Herzegovina7', 'Defence White Paper of Bosnia and Herzegovina'8, as well as other documents defined NATO membership of BiH as a strategic goal. However, the official state-level NATO policy is shaped by both external

7 For more, see: Presidency of Bosnia and Herzegovina (2003).

8 For more, see: Defence White Paper of Bosnia and Herzegovina (2005: 5, 12, 14, 15 and other). 
and internal factors which at the moment prevent BiH from joining MAP. In fact, with the internal and external factors that prevail, even the state official documents are indicators that show that the NATO integration process of $\mathrm{BiH}$ differs from the process in other Western Balkan and East European countries.

\section{Ideology of consociationalism}

The majority of Balkan and East European countries are NATO member states. Those countries built their political systems on the tradition of parliamentary or semi-presidential political systems. These two political systems enabled the above-mentioned countries to pass more easily through the reforms to become member states of the EU and/or NATO. On the other hand, BiH's political system is built on the foundations of the federal parliamentary republic, encompassing the tradition of the consociational democracy defined by the Dayton Peace Agreement in 1995. With such a political system, $\mathrm{BiH}$ is unable to reach a consensus on the internal reforms needed for membership of the EU and NATO.

In order to prevent a relapse into violence in $\mathrm{BiH}$, the international community outlined a comprehensive agreement for $\mathrm{BiH}$ and all the warring sides. It meant that post-war BiH would be based on four traditional consociational institutions. However, it did not end there. The new political system went into further 'complex consociationalism' "in the sense that it also outlines the institutional structure of the state, autonomy provisions for the state's entities and cantons, the judicial system, the role of the international community within the state, the economy, issues of security sector reform, and the right of the return of refugees and displaced persons" (Fleet 2014: 19). The constitutional system is based on the pattern of a power-sharing model in which the collective rights of three dominant ethnic groups in BiH take superiority over the rights of the individual/citizen. In addition, the national political parties are seen as the only legitimate representatives of each ethnic group, which results in ethno-political 'elites'. 
A key condition for the functioning of any democratic society is the existence of minimum political consensus about accepting the community in which they live (Balic and Izmirlija 2013). In the case of $\mathrm{BiH}$, it is hard even to talk about the minimum consensus, since the Bosnian Constitution has never been ratified in the State Parliament. Also, the ethno-religious political representatives in $\mathrm{BiH}$ still have difficulty agreeing on the reform policy/agenda which could accelerate the Euro-Atlantic integration process. There are many reasons for their disagreement: different interpretations of the country's history by the constituent peoples, the role of the international community, and the influence of the foreign policy of neighbouring countries - particularly Serbia and Croatia - on the foreign policy of $\mathrm{BiH}$. In addition, complex decision-making procedures grounded in the consociational democracy affect the NATO integration process of $\mathrm{BiH}$ in many negative ways.

The Dayton Peace Accord in BiH serves as an example of the formal institutionalization of mutual vetoes: it devised a formula that at least onethird support from each of the three constituent groups is required for all decisions in the House of Representatives. The same works for the House of Peoples at the state level. The proportionality principle in $\mathrm{BiH}$ is required in nearly every aspect of government and civil services. Additionally, BiH has a three-person presidency with one seat reserved for each of the three constituent peoples (Bosniaks, Bosnian Serbs and Bosnian Croats). Each member of the presidency is elected by the members of the community he is to represent (McCulloch 2009). As for the veto, each of the three presidents can invoke a veto on policies that they view as 'dangerous' to the 'vital interest' of the ethnic group they represent in the presidency of $\mathrm{BiH}$. However, when this happens, the National Assembly of the Republika Srpska or the BiH parliament (House of Peoples) can override a presidential veto by a two-thirds majority vote. The Bosnian multi-ethnic diversity and the ethnic-based representation in state-level institutions (and the entity level), as well as the aggravating political circumstances in $\mathrm{BiH}$, often do not allow BiH to progress towards Euro-Atlantic integration. It is hard, and it is getting harder, to satisfy all the sides in $\mathrm{BiH}$, and $\mathrm{BiH}$ therefore faces many challenges in the integration process and the fulfilment of indispensable reforms. Ostrom (1990) suggests that collaborative decisionmaking and reforms work best in countries when the population is small and homogenous. 


\section{NATO involvement in a non-member state: the Bosnian War 1992-1995}

When it comes to NATO membership, the Bosnian experience of NATO shapes its decision-making process regarding integration, and it is often used for public justification of a decision not to become a NATO member state, particularly in Republika Srpska. The relationship between $\mathrm{BiH}$ and NATO is in many ways unique and the NATO intervention in BiH is described as a 'milestone' of the relationship (Kivimaki, Kramer and Pasch 2012).

The NATO alliance intervened in BiH in 1995 as a consequence of war crimes and the suspension of the Geneva Convention (NATO 2005). BiH became the first non-NATO member state in which the Western Alliance conducted military operations. In addition, military operations led by NATO during the 1990s in BiH, Serbia and Kosovo have had a significant influence on the NATO integration process, as well as on the population in these Western Balkan countries. For instance, the president of Republika Srpska, Milorad Dodik, said that Republika Srpska formed its view towards NATO (a negative tendency towards the membership), and pointed out that the NATO bombing of Serbs in Republika Srpska influenced the formation of such an attitude, especially because the NATO bombings determined the outcomes of the (Bosnian)war (Nezavisne novine 2016).

However, NATO's intervention in 1995 and NATO's post-war reconciliation role in $\mathrm{BiH}$ minimized the likelihood of repeated large-scale hostilities among the ethnic groups. The NATO membership of BIH depends on the political elites and their ability to harmonize their divided approach towards NATO membership. The 1995 NATO intervention in BiH targeted the Bosnian Serbs who refused to comply with the Geneva Convention, which created a favourable situation for the Bosniaks and Bosnian Croats: this is why it is difficult for the Bosnian government to get the support of the Bosnian Serbs for NATO membership. 


\section{The role of the international community: protector of social order and the statehood}

The end of the Bosnian war and enforcement of the Dayton Peace Accords in 1995 defined the role of the international community (IC) in the country. The IC is obliged to monitor the accords from the peace agreement and help the warring parties overcome various challenges. $\mathrm{BiH}$, because of the presence of the $\mathrm{IC}$, could have been classified as a country with (semi-) protectorate status in international relations. The presence of the $\mathrm{IC}$ is perhaps the key difference between $\mathrm{BiH}$ and other countries in Eastern Europe and Western Balkan.

The OHR, as the main institution of the $\mathrm{IC}$ in $\mathrm{BiH}$, is responsible for monitoring the Dayton Peace Accords in the country. It is also the only interpreter of the DPA in case of any major political disputes between the conflicting parties. The OHR "is working with the people and institutions of Bosnia and Herzegovina and the international community to ensure that Bosnia and Herzegovina evolves into a peaceful and viable democracy on course for integration in Euro-Atlantic institutions" (OHR n.d.: i). The period of the OHR intervention in the politics of $\mathrm{BiH}$ can be divided into several phases: (1) the period of interest of the IC without direct interference; (2) the period of interest of the IC by strengthening the role of the OHR in domestic politics in $\mathrm{BiH}$; (3) the period of withdrawal of the IC and the policy of silence of the $\mathrm{OHR}$ in $\mathrm{BiH}$; and (4) the period of shutting down the OHR in $\mathrm{BiH}$ once the country fulfils the required criteria (Borić 2012).

Most of the reforms that supported the Euro-Atlantic integration process emerged out of the active involvement of OHR and other international institutions in $\mathrm{BiH}$, such as the EU Delegation and NATO. At the moment, the OHR policy is in its third stage, the period of withdrawal of the IC and silence of the OHR in BiH. This stage of the OHR policy is a test for the domestic institutions which perhaps failed to show the results that the OHR policy-makers desired. The failure of the political leaders to meet the criteria specified by the third OHR stage was clearly demonstrated 
with the illegal referendum organized by the Republika Srpska (RS) on 25 September 2016. The referendum was held in spite of the ban imposed by the High Court of BiH and the outcry of the OHR. According to a statement by Valentin Incko, the High Representative, the purpose of the handsoff approach by the OHR was to provide the institutions in $\mathrm{BiH}$ with the opportunity to strengthen and mature (BBC 2016b). However, this policy proved itself non-functional, and it seems that the third stage of the OHR policy will succeed only when the entities demonstrate mature politics and start paying respect to the state institutions.

The aggravating political circumstances in $\mathrm{BiH}$ prevent the OHR from entering into the fourth stage, the period of shutting down the OHR in $\mathrm{BiH}$. This stage of the OHR requires more analysis than the previous stages, as it could lead the country to new political instability. Therefore, the OHR is delaying its withdrawal from $\mathrm{BiH}$ until the required criteria are met by the political elites in both entities. Very often BiH has only functioned because of the presence of the 'protector' - that is, the IC and OHR as the executive body. The OHR is very clear regarding its presence in $\mathrm{BiH}$ : if $\mathrm{BiH}$ wants to free itself from the OHR presence, the country must establish a different political system (International Crisis Group 2014). Also, without the support of all the member states of the Peace Implementation Council (PIC), the OHR is currently in a sort of geopolitical vacuum and as such it is unable to exert more influence over the Bosnian political decision-makers.

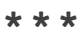

\section{The influence of neighbouring countries in the NATO integration policy}

In terms of external actors, the influence of the neighbouring countries of $\mathrm{BiH}$ - called guarantors of the DPA - affects the attitude of Serbs and Croats in $\mathrm{BiH}$ to a significant extent. In the geopolitical context, the alleged Serbian foreign policy influence failed in preventing Montenegro from NATO integration. Unlike their status in $\mathrm{BiH}$, the Serbian population could not use the institutional mechanism, asking for protection of 'vital national interest' in order to block the Montenegrin NATO membership. The membership of Montenegro is a historic turn towards the West and 
away from its traditional ally, Russia. Janusz Bugajski, a Senior Fellow at the Centre for European Policy Analysis, stated that "Montenegro's membership in NATO could change the way Serbians view the alliance" (B92 2017: i). However, this might be difficult to achieve in reality as a large part of the population and political elites in Serbia consider Russia as a reliable ally. ${ }^{9}$ Serbia is balanced between EU membership, partnership with NATO and cooperation with Russia.

BiH's NATO membership could contribute to an upgrade of the Western Balkans' security situation, as the NATO member states do not fight against each other and jointly contribute to common security. Analysing the security policy of $\mathrm{BiH}$, it can be argued that NATO membership would play a significant role in the security of the entire region. The NATO Secretary General Anders Fogh Rasmussen said "NATO's vision for the Western Balkans region is clear: Euro-Atlantic integration is the best guarantee for peace, progress and prosperity" (NATO 201 1). Regardless of this statement and many international NATO documents that guarantee Bosnia security under the Alliance, BiH still needs to do a lot in order to meet NATO requirements for integration. In short, Bosnian NATO integration conflicts with the influence of regional actors and their attitudes and interests.

Serbia and Croatia have substantial political influence on $\mathrm{BiH}$ because of the significant Serbian and/or Croatian population in $\mathrm{BiH}$ and due to the fact that both of these countries were signatories of the DPA. Based on contextual analysis of the available statements by some of the top politicians, it can be concluded that Croatia and Montenegro support BiH's NATO membership. Croatian President Kolinda GrabarKitarovic expressed Croatia's willingness to support BiH in the EU and NATO integration process. "Personally, I advocate and I will advocate for Bosnia and Herzegovina's European integration, because I see Bosnia and Herzegovina as a member of the EU and NATO as soon as possible, because it is a prerequisite for a lasting peace and a better life for all citizens in Bosnia and Herzegovina" (Hrvatski medijski servis 2015, author's translation). The idea behind Grabar-Kitarović attitude is to ensure and improve security in the Western Balkans. NATO membership would help $\mathrm{BiH}$ become a stable and reliable regional player.

9 The Survey of Serbian Public Opinion, 24 November 2015-3 December 2015, conducted by Centre for Insight in Survey Research, showed that 94 per cent of interviewees think that Serbia's interests are best served by maintaining strong relations with Russia, while only six per cent of interviewees disagreed with this statement. 
Actual interference of regional countries that has an unfavourable effect on BiH's NATO integration is seen in Serbia. It is demonstrated in the political statements and decisions by both Serbs in BiH and Serbia. The President of Republika Srpska, Milorad Dodik, said that public opinion in the RS is overwhelmingly against joining NATO, adding that "it is a dangerous situation for Serbia to remain neutral, and the RS goes to membership in the military organization" (Nova srpska politička misao 2015, author's translation). In addition, Serbia accepted the Declaration of military neutrality in 2007, the effects of which are visible in the BiH integration process. The Serbian decision not to become a NATO member state from 24 March 2017 was confirmed by Aleksandar Vučić, the President of Serbia, who said that "Serbia will never look for NATO membership, and [Serbia] will not allow the suffering of Serbs to be repeated" (Nezavisne novine 2017: xvi, author's translation). This has had a negative impact on the NATO integration of BiH because political leaders in RS stated that they would align with Serbia regarding NATO cooperation. The Serb member of the Presidency of $\mathrm{BiH}$, Mladen Ivanić, stated: "I can only repeat that in NATO we can enter only if and when the Alliance enters Serbia. The position cannot be clearer position than this. Any other option would include the division of the Serbian people. We do not need referendums. The subject does not even need to be opened because of Bosnia and Herzegovina's membership in NATO; there is no requirement as long as Serbia is not in the Alliance" (Politika 2015: vii, author's translation). Such a policy is also included in the political programmes of the Serbian political parties in $\mathrm{BiH}$. For instance, the political platform of the Serbian Democratic Party (SDS) promotes the military neutrality of $\mathrm{BiH}$ and adherence to the [military] status of Serbia, ${ }^{10}$ while the "Serbian Democratic Party fully opposes the idea of the Republic of Srpska being a part of NATO" (Serb Democratic Party of Bosnia and Herzegovina n.d.: 72).

10 The "Serbian Democratic Party sees military neutrality and demilitarization of the Republic of Srpska and BiH as the only realistic policy in this region. It is a genuine interest of the Republic of Srpska to have identical status as that of the Republic of Serbia in order to prevent some situations that had occurred in a relatively recent past period that Serbs from two sides of Drina River find themselves on two opposed military sides against each other" (Political Programme of SDS n.d.:71). 


\section{Conclusion}

The NATO security matrix in the Western Balkans contains elements of peace, stability and security from the perspective of one group, Bosniaks and Bosnian Croats, and elements of instability, insecurity and danger from the perspective of another, Bosnian Serbs. Such a security environment thus produces positive and negative effects on the security of the Western Balkan countries. Both of the above-mentioned perspectives are the result of either internal or external factors. The divergent opinions on this question range from opportunistic press releases to enthusiastic support for the membership; or from NATO-centric to NATO-sceptic attitudes. These diverging attitudes would not be problematic if $\mathrm{BiH}$ had other alternatives. Other current NATO member states had similar attitudes prior to accession, but none of the current NATO member states in East Europe and the Western Balkans were faced with the internal and external factors with which $\mathrm{BiH}$ is faced at the moment. The idea of this paper is not to suggest that the current NATO member states passed through the NATO integration process easily, but rather that, due to its specificities, BiH has been maintaining a status quo over the last few years. It is important to emphasize that during this period $\mathrm{BiH}$ has not lost much, but the option to return to the status quo ante, or state of affairs that existed previously, is still a real threat.

A certain body of literature and media reports has failed to identify the 'specifics' of $\mathrm{BiH}$ and as a result many researchers interested in Bosnian NATO integration have not been able to grasp the whole picture of the Bosnian path to NATO. This study has identified four major specifics of $\mathrm{BiH}$ that make its integration process different from other countries. Because of the specifics analysed in this paper, this study aimed to address the following questions: (i) whether domestic politics influence the foreign policy of $\mathrm{BiH}$; and (ii) to what extent the neighbouring countries determine the foreign policy of $\mathrm{BiH}$ regarding NATO. A clear-cut distinction between these two factors was not identified, firstly, because two of the specifics determine the 'domestic political view' on the NATO membership of BiH: (i) NATO involvement in the Bosnian war 1992-1995 and (ii) the country's consociationalism. NATO involvement in the Bosnian war has created NATO-centric or NATO-sceptic approaches, depending on the ethnic 
group, and Bosnian consociationalism is a mechanism which transforms these approaches into policies. Due to its current political system, the will of the 'opposition' prevails over others by using the mechanisms of the entity vote and protection of vital national interests. As noted above, Mladen Ivanić, the Serb member of the BiH Presidency, pointed out that the unsolved issue of property defence is an instrument freezing the process of BiH integration into NATO. He added that "it is easier for [politicians from the Republika Srpska] to talk about a dispute over property than a dispute over membership in NATO" (Bećirević, Ćurak and Turčalo 2014:34). This attitude has slowed down BiH's NATO membership regardless of the other constituent peoples' will to join. The attitude of the Bosnian Serbs is the result of war events, but mostly their sympathy towards Russia and Serbia. Secondly, Bosnian foreign policy and its attitude towards NATO membership are not only shaped by domestic factors, but rather jointly with external factors. Often, Bosnian foreign policy cannot avoid the influence of external factors - that is, interference by Serbia and Croatia. This leaves enough room for future research to address the question of the extent to which $\mathrm{BiH}$ creates its foreign policy independently. In addition, Serbian politicians in $\mathrm{BiH}$ sent a clear message on a number of occasions that the military status of BiH would be determined by the military status of Serbia - that is, if Serbia stays out of NATO, BiH will do the same. On the other hand, Croatia showed readiness to support the Euro-Atlantic integration of $\mathrm{BiH}$, at least officially.

Lastly, because of all of the Bosnian specificities, this paper has advocated that the aspiration of $\mathrm{BiH}$ to become a NATO member state cannot be viewed through the prism of other NATO member states' accession processes. The Bosnian challenges of NATO integration are much more complex than any other challenges that the existing NATO member states had to face. The external influence to prevent $\mathrm{BiH}$ from NATO integration remains the most challenging barrier in the process. 


\section{Bibliography}

B92, 2017. With Montenegro in, Serbians could view NATO differently. B92, 15 May [online]. Available at: http://www.b92.net/eng/news/ world.php? yyyy $=2017 \& \mathrm{~mm}=05 \& d d=15 \&$ nav_id=101274 (Accessed 13 May 2017).

Balic, L. and Izmirlija, M., 2013. Consociation in Bosnia and Herzegovina: practical implementation of the theoretical principles. South-East European Journal of Political Science, 1(3): 121-135.

BBC, 2016a. Bosnian Serb referendum backs disputed 9 January holiday. BBC, 25 September [online]. Available at: http://www.bbc.com/ news/world-europe-37465653 (Accessed 8 May 2017).

BBC, 2016b. Bosnian Serb referendum challenges peace terms. BBC, 24 September [online]. Available at: http://www.bbc.com/news/ world-europe-37453147 (Accessed 8 May 2017).

Bećirević, E., Ćurak, N. and Turčalo, S., 2014. The state and its property: an analysis of the politics. Sarajevo: Atlantic Initiative.

Benyon, R., 2017. Economic transition in the Western Balkans: an assessment. NATO Parliamentary Assembly, Economics and Security Committee. Reference number: 074 ESCTD $17 \mathrm{E}$.

BN, 2015. Modernizacija vojske, BiH nema sredstava. BN Televizija, 30 October [online]. Available at: https://www.rtvbn.com/363343/Modernizacijavojske-BiH-nema-sredstava (Accessed 30 August 2017).

Borić, F., 2012. Perspektive euroatlantskih integracija. Sarajevo: Centre for Policy and Governance, [pdf]. Available at: http://www.cpu. org.ba/media/7970/Perspektive-euroatlantskih-integracija.pdf (Accessed 20 May 2017).

Case No IT-95-14-A, 1998a. Testimony by S. Mesić from 16 to 19 March 1998.

Case No IT-95-14-A, 1998b. Testimony by academician Dušan Bilandžić, 9 September 1998, pp. 11389-11390.

Centre for Insight in Survey Research, 2015. Survey of Serbian public opinion. 
[pdf]. Available at: http://www.iri.org/sites/default/files/wysiwyg/ serbia_november_2015_poll_public_release.pdf (Accessed 2 June 2017).

Croatian Information Centre, 1993. Great Serbia from Ideology to Aggression. Beljo, A., (Chairman), Bosnar, E., Bing, A., Ercegovac Jambrovic, B., and Skrlin, N. eds. Croatia: Zagrebacka Tiskara. Available at: http://www.hic.hr/books/greatserbia/index.htm (Accessed 30 August 2017).

Defence White Paper of Bosnia and Herzegovina, 2005. Defence White Paper of Bosnia and Herzegovina. Ministry of Defence of the Republic of Bosnia and Herzegovina, [pdf]. Available at: http:// www.mod.gov.ba/files/file/dokumenti/defense/engwhitebook. pdf (Accessed 20 May 2017).

Defence Reform Commission, 2003. The path to the partnership for peace. [online]. Available at: https://wmw.google.ba/url?sa=t\&rct=j\&q=\&esrc= s\&source=web\&cd=1\&cad=rja\&uact=8\&ved=0ahUKEwjA6pjeg8DNAhV OkRQKHYdMDWIQFggbMAA\&url=https\%3A\%2F\%2Fwww.jfcnaples.nato. int\%2Fsystems\%2Ffile_download.ashx\%3Fpg\%3D1441\%26ver\%3D1\&usg=A FQjCNEMgi5-_Dbuap7Kah7F_FeMJOZqfw\&sig2=rN1 oYjLKHx-QjhLCjBLENg (Accessed 1 May 2017).

Deutsche Welle, 2016. Serbo-Croatian rivalry fuelling arms race in the Balkans. DW, 15 January [online]. Available at: http://www. dw.com/en/serbo-croatian-rivalry-fueling-arms-race-in-thebalkans/a-18983163 (Accessed 26 June 2017).

Faktor, 2017. Dodik ponovo prijeti: Smjena glavnog revizora RS-a, demilitarizacija i novi zakon o knjiženju vojne imovine. Faktor, 29 August [online]. Available at: https://www.faktor.ba/vijest/dodikponovo-prijeti-smjena-glavnog-revizora-rs-demilitarizacija-i-novizakon-o-knjizenju-vojne-imovine-262714 (Accessed 30 August 2017).

Fearon, J. D., 1998. Domestic politics, foreign policy, and theories of international relations. Annual Review of Political Science, 1: 289-313.

Fleet, M. J., 2014. Nationalism and multi-ethnic governance in BosniaHerzegovina: a study of consociationalism and centeripetalism. Mapping Politics, 6(2): 16-24. 
Global Firepower, 2017a. Bosnia and Herzegovina. Global Firepower, [online]. Available at: https://www.globalfirepower.com/countrymilitary-strength-detail.asp? country_id=bosnia-and-herzegovina (Accessed 30 August 2017).

Global Firepower, 2017b. Croatia. Global Firepower, [online]. Available at: https://www.globalfirepower.com/country-military-strengthdetail.asp?country_id=croatia (Accessed 30 August 2017).

Global Firepower, 2017c. Serbia. Global Firepower, [online]. Available at: https://www.globalfirepower.com/country-military-strength-detail. asp? country_id=serbia (Accessed 30 August 2017).

Grizold, A. and Vegic, V., 2001. Small states and alliances: the case of Slovenia. In: Reiter, E. and Gärtner, H. eds. Small states and alliances. Germany: Springer-Verlag. pp. 145-161.

Hrvatski medijski servis, 2015. Grabar Kitarović i Dodik razgovarali o povratku Hrvata $\cup$ RS i Srba $\cup$ RH. HMS, 12 September [online]. Available at: http://hms.ba/grabar-kitarovic-i-dodik-razgovarali-opovratku-hrvata-u-rs-i-srba-i-rh/ (Accessed 28 March 2017).

International Crisis Group, 2012. Bosnia's Gordian knot: constitutional reform. Europe Briefing No. 68, [pdf]. Available at: https://www. files.ethz.ch/isn/150698/b068-bosnias-gordian-knot-constitutionalreform.pdf (Accessed 3 February 2017).

International Crisis Group, 2014. Bosnia's future. Europe Reform No. 232, [pdf]. Available at: https://d2071 andvip0wj.cloudfront.net/bosnias-future.pdf (Accessed 7 February 2017).

Kivimaki, T., Kramer, M. and Pasch, P., 2012. The dynamics of conflict in the multi-ethnic state of Bosnia and Herzegovina. Friedrich-EbertStiftung (FES), [pdf]. Available at: http://library.fes.de/pdf-files/ bueros/sarajevo/09418.pdf (Accessed 14 March 2017).

Liska, G., 1962. Nations in alliance: the limits of interdependence. Baltimore, MD: Johns Hopkins Press.

McCulloch, A., 2009. Seekingstabilityamid deepdivisions: consociationalism and centripetalism in comparative perspective. [e-thesis]. Available at: https://qspace.library.queensu.ca/bitstream/1974/1708/1/ 
McCulloch_Allison_200902_PhD.pdf (Accessed 12 February 2017).

Milinkovich, V., 2016. NATO enlargement in the Western Balkans. 29 June [online]. Available at: katehon.com/article/nato-enlargementwestern-balkans (Accessed 5 May 2017).

Ministry of Defence, Bosnia and Herzegovina, 2011. Brochure. [pdf]. Available at: www.mod.gov.ba/files/file/maj_2011/bosura\%20 eng\%20mail.pdf (Accessed 15 May 2017).

Nezavisne novine, 2016. Dodik: Srbi U Srpskoj i Srbiji pamte NATO bombardovanje. Nezavisne novine, 27 February [online]. Available at: http://www.nezavisne.com/novosti/bih/Dodik-Srbi-u-Srpskoj-i-Srbijipamte-NATO-bombardovanje/356478 (Accessed 27 March 2017).

Nezavisne novine, 2017. Vučić: Srbija nikada neće tražiti da uđe u NATO; Dodik: Kako zaboraviti?. Nezavisne novine, 24 March [online]. Available at: http://www.nezavisne.com/novosti/ex-yu/ Vucic-Srbija-nikada-nece-traziti-da-udje-U-NATO-Dodik-Kakozaboraviti/418754 (Accessed 28 June 2017).

North Atlantic Treaty Organization, 4 April 1949. North Atlantic Treaty, Article 10. (last updated 21 March 2016) [online]. Available at: http://www.nato.int/cps/en/natohq/official_texts_17120.htm (Accessed 13 May 2017).

North Atlantic Treaty Organization, 2005. Bringing peace and stability to the Balkans. [pdf]. Available at: http://www.nato.int/nato_static/ assets/pdf/pdf_publications/20120103_balkans-e.pdf (Accessed 7 February 2017).

North Atlantic Treaty Organization, 2011. NATO and the Western Balkans. Speech by NATO Secretary General Anders Fogh Rasmussen Budva, Montenegro, [online]. Available at: www.nato.int/cps/fr/ natohq/opinions_75860.htm (Accessed 15 May 2017).

North Atlantic Treaty Organization, 2012. Chicago Summit declaration. [online]. Available at: www.nato.int/cps/en/natohq/official_ texts_87593.htm?selectedLocale=en (Accessed 13 May 2017).

North Atlantic Treaty Organization, 2014a. Partnership for peace status of forces agreement. [online]. Available at: www.nato.int/cps/on/ natohq/topics_50086.htm (Accessed 2 June 2017). 
North Atlantic Treaty Organization, 2014b. Partnership for Peace Planning and Review Process. [online]. Available at: http://www.nato.int/ cps/en/natohq/topics_68277.htm (Accessed 9 March 2017).

North Atlantic Treaty Organization, 2017a. Individual partnership action plans. [online]. Available at: www.nato.int/cps/on/natohq/ topics_49290.htm (Accessed 13 May 2017).

North Atlantic Treaty Organization, 2017b. Partnership for peace programme. [online]. Available at: www.nato.int/cps/en/natolive/ topics_50349.htm (Accessed 13 May 2017).

North Atlantic Treaty Organization, 2017c. Relations with Bosnia and Herzegovina. [online]. Available at: www.nato.int/cps/it/natohq/ topics_49127.htm (Accessed 4 May 2017).

Nova srpska politička misao, 2015. Milorad Dodik: Srpska protiv ulaska u NATO, nejasno koliko je dobro članstvo u EU. Nova srpska politička misao, [online]. Available at: http://www.nspm.rs/hronika/miloraddodik-srpska-protiv-ulaska-u-natonejasno-koliko-je-dobro-clanstvou-eu.htmle alphabet=l (Accessed 3 May 2017).

OHR, n.d. General information. Office of the High Representative, [online]. Available at: http://www.ohr.int/?page_id=1139 (Accessed 3 May 2017).

OSCE, 2014a. A new era for South-East Europe: rebuilding peace, security and stability in aftermath of war. 25 November [online]. Available at: www.osce.org/cio/126754 (Accessed 19 August 2017).

OSCE, 2014b. Bosnia and Herzegovina, Croatia, Montenegro and Serbia take ownership of regional arms control. Dayton Peace Agreement Article IV Annex 1/B: Mission accomplished. 4 Decembber [online]. Available at: www.osce.org/cio/129436 (Accessed 19 August 2017).

Ostrom, E., 1990. Governing the commons. The evolution of institutions for collective action. New York: Cambridge University Press.

Pantovic, M., 2016. Serbia arms experts query value of Russia's 'gifts'. Balkan Insight, 23 December [online]. Available at: www. balkaninsight.com/en/article/serbian-arms-deal-with-russia-maybe-†oo-expensive-12-22-2016 (Accessed 25 June 2017). 
Politika, 2015. U NATO mozemo ući samo ako U njega uđe Srbija. Politika, 13 April [online]. Available at: http://www.politika.rs/scc/ clanak/324583/U-NATO-mozemouci-samo-ako-U-njega-ude-Srbija (Accessed 6 May 2017).

Pond, S., 2004. Understanding the PfP tool kit. Taking NATOs partnership forward/NATO review. [online]. Available at: wWw.nato.int/docu/ review/2004/issue 1/english/art2.html (Accessed 12 March 2017).

Presidency of Bosnia and Herzegovina, 2003. General directions and priorities for implementation of foreign policy of Bosnia and Herzegovina. 26 March [online]. Available at: www. predsjednistvobih.ba/vanj/default.aspx?id=13612\&langTag=en-US (Accessed 12 March 2017).

Radio Slobodna Europa, 2016. Vučić i Dodik: Srbija i RS čuvaju vojnu neutralnost. Radio Slobodna Evropa, 26 February [online]. Available at: https://wmw.slobodnaevropa.org/a/vucic-i-dodik-srbija-i-rs-cuvajuvojnu-neutralnost/27576180.html (Accessed 30 August 2017).

RTRS, 2017. SNSD, DNS i SP: NSRS da usvoji status o vojnoj neutralnosti, traži se ostavka revizora. Radio televizija Republike Srpske, 29 August [online]. Available at: http://lat.rtrs.tv/vijesti/vijest.php?id=267234 (Accessed 30 August 2017).

Serb Democratic Party of Bosnia and Herzegovina, n.d. Party program of the Serbian Democratic Party. [pdf]. Available at: http://www.sdsrs. com/dokumenti/Program_sDSeng.pdf (Accessed 7 May 2017).

Sputnik, 2017. The Serbian army on Tuesday received military equipment worth around 900,000 euros ( 1 million US dollars) donated by China. Sputnik News, 21 June [online]. Available at: https://sputniknews. com/military/20170621 1054823287-china-donates-military-serbianarmy/ (Accessed 9 August 2017).

Tuđman, M, 2015. 48 Absurd meetings between Tuđman and Milošević. National Security and the Future 2-3(16): 121-172.

United Nations, 1995. Dayton peace agreement. [pdf]. Available at: www. peacemaker.un.org/sites/peacemaker.un.org/files/BA_951121_ DaytonAgreement.pdf (Accessed 14 May 2017). 
Walt, M. S., 1987. The origins of alliances. Ithaca, NY: Cornell University Press.

Warren, C. P. T., 2010. Alliance history and the future NATO: what the last 500 years of alliance behaviour tells us about NATO's path forward. Foreign Policy at Brookings: 21st Defence Initiative Policy Paper, [pdf]. Available at: https://www.brookings.edu/wp-content/ uploads/2016/06/0630_nato_alliance_warren.pdf (26 February 2017).

Hamza Preljević (hpreljevic@ius.edu.ba) is a Senior Assistant at the Department of International Relations (IR) at the International University of Sarajevo (IUS). He is also a PhD student in IR at IUS. His areas of interest are the politics of Bosnia and Herzegovina, Western Balkan studies, EU integration, EU foreign policy and security study, with active research into different aspects of transatlantic relations and NATO's relations with the Western Balkans. He lectures on the political system of Bosnia and Herzegovina, and on political violence and terrorism. 